\title{
Opportunities for and Limits to Cooperation between School and Families in Sustainable Public Food Procurement
}

\author{
Elena Pagliarino*(D), Elena Santanera and Greta Falavigna \\ CNR-IRCRES, Research Institute on Sustainable Economic Growth, Italian National Research Council, \\ 10024 Moncalieri, Italy; elenasantanera7@gmail.com (E.S.); greta.falavigna@ircres.cnr.it (G.F.) \\ * Correspondence: elena.pagliarino@ircres.cnr.it
}

Citation: Pagliarino, E.; Santanera, E.; Falavigna, G. Opportunities for and Limits to Cooperation between School and Families in Sustainable Public Food Procurement.

Sustainability 2021, 13, 8808

https://doi.org/10.3390

/su13168808

Academic Editors: Sergio Schneider, Luana F. Joppert Swensson,

Florence Tartanac, Mark Stein and Danny Hunter

Received: 25 June 2021

Accepted: 3 August 2021

Published: 6 August 2021

Publisher's Note: MDPI stays neutral with regard to jurisdictional claims in published maps and institutional affiliations.

Copyright: (C) 2021 by the authors. Licensee MDPI, Basel, Switzerland. This article is an open access article distributed under the terms and conditions of the Creative Commons Attribution (CC BY) license (https:/ / creativecommons.org/licenses/by/ $4.0 /)$.

\begin{abstract}
This paper describes a research project, carried out in an Italian public school, to assess whether parents were willing to take part in food procurement decisions, as well as their ability to accurately predict what foods children would pick at school lunch and their propensity to support sustainable food choices made by the school. The methodology included a questionnaire, issued to 500 parents, and an in-depth study of 138 child/parent pairs. The study comprised: (i) presentation of an innovative recipe in the weekly menu of the school canteen; (ii) meal observations of children's intake at school lunch during the week of the menu modification; (iii) collection of both parents' and children's reports on their choices of recipes from the modified weekly menu. The results are commented in light of two important changes that have recently affected Italian public school food procurement: the opening of school canteens to lunches brought from home and the measures adopted since 2020 to contain the COVID-19 pandemic. Both events go in the direction of delegating to parents the multifaceted role of the school in the food arena. The article concludes that the results of the study should discourage this approach.
\end{abstract}

Keywords: school catering; sustainable food; public procurement; parents; children; food choices; involvement; COVID-19 pandemic

\section{Introduction}

Extensive literature has shown that school feeding programs can address major food challenges-such as eradication of hunger [1,2], reduction of obesity and other food-related diseases [3-7], development of local economies, ecological sustainability and the ethics of food systems [8-15], education of consumers on food-related issues [16,17]-and bring about a mix of social, economic and environmental outcomes at the same time [18-22].

School meals play an important role in providing access to sufficient and safe nourishment for all, in both developed and developing countries, through nationwide, regional or local programs of free or heavily subsidized meals and breakfasts [23-28], guidelines on proper food preparation and consumption during school meals [29-31] and food education [17,32-34]. The school lunch is an educational moment in itself $[17,35]$ and, in association with food educational activities, such as kitchen literacy courses, school-based gardening, farm visits, etc., it constitutes "a 'whole school' approach, in which the message of the classroom is echoed in the canteen" [36] (p. 6), teaching pupils food knowledge and correct habits $[17,36,37]$. Schools are also involved in the fight against obesity by providing healthy and balanced meals, avoiding junk food and beverages and offering opportunities for sport and physical activity [32,38-44]. Public school lunch programs are considered democratic tools to reach educational and social goals, because actions carried out at school may succeed in uniformly influencing the food behavior of numerous children simultaneously, reaching out to all socio-economic classes in a given nation $[4,22,27,45,46]$.

The opportunity to interact with local producers (i.e., farm-to-school programs) and the preference for organic, fair trade, seasonal and fresh products in public food procurement has supported the socio-economic development and environmental sustainability of 
the food supply chain $[9,27]$. The diversification of school menus has been used as a tool to make room for cultural diversity and inclusion of different food choices for religious, ethnic and ethical reasons. Finally, the school lunch is considered a tool for gender justice, by promoting feminist goals, such as the social and economic recognition of those who perform the work of school feeding [47] and by providing care services outside the family, such as childcare during lunchtime at school, thus contributing to increased maternal labor force participation [48].

The school meal is all of this. Gaddis and Coplen [47] say that, at its core, the school lunch is about caring for children. The act of feeding children - they continue [47] (p. 2)-is crucial for social reproduction, regarded by Giovanna Di Chiro [49] (p. 281) as "the intersecting complex of political-economic, sociocultural, and material-environmental processes required to maintain everyday life and to sustain human cultures and communities on a daily basis and intergenerationally". In several countries, such complex responsibilities are shared between school and families. In Italy, for example, children eat their mid-morning breakfast and lunch at school on average 200 days a year, and their calorie intake from school meals is equal to $40-50 \%$ of the recommended daily allowance [50-53].

Even though they share this responsibility, the two feeding environments (home and school) are almost completely separate; in addition, the role played by parents in education programs and procurement decisions related to school food is disregarded in governmental action. Parents undoubtedly have a large stake in school meals, since they actually outsource a portion of their feeding responsibilities to schools [54]. They often pay for the service, in whole or in part depending on their income [22]. Parents (mostly mothers) have also actively contributed to devising school lunch programs through individual initiatives, triggering collective interventions to increase the availability of healthy food and limit the presence of unhealthy options [45-57]. Constant and transparent communication between schools and parents is crucial to allow children to acquire healthy and sustainable food behaviors at home and school. The implementation of new technologies can help create stronger synergies between schools and parents for what concerns food. For instance, Swedish parents can download an app that lets them see what food their children were given at school, so that they can prepare something different for the evening meal [58].

In some cases, the relationship between school and families is negative and counterproductive. Several authors [59-61] have pointed out that some schools become paternalistic and authoritarian in their intent to educate parents; they target school lunchboxes and prescribe what parents can and cannot pack in their children's lunch. For their part, parents may resist school policies by sneaking food into their children's schoolbag or by producing false documentation about food intolerances, so that the school has no choice but to offer food that their children actually enjoy eating [62]. Familial habits and school food policies may be in direct opposition [63]. Oncini [62] concludes that parents regard meal policies as a mere imposition and not as a process in which all of the actors' work toward reaching a shared educational objective.

Instead, the opinions of parents on school food would count much more if they simply took on a more active role, with greater commitment and awareness, as experimented by Kalafa [64]. A more hand-on approach would allow parents to better understand public choices and identify actors that can help pursue common educational goals [62]. Stein [65] argues that the English public food procurement (PFP) initiative, "Food for Life Partnership", owes its success to its embedding in the wider community of the schools, towns and cities where it operates and the ability to bring together the ideas, not only of the school and catering personnel, but also of the pupils and the parents in decisions about the school menu. Although there is a general consensus on the importance of community engagement, including parents and children, for the success of sustainable school food interventions [66-68], little research has been done on the role of parents, on how they influence school food decisions and their children's school food choices.

This paper contributes to filling the literature gap on the role of parents in sustainable PFP exploring the opportunities for and limits to cooperation between schools and families. 
The novelty of our research consists in analyzing the propensity and the capacity of parents to support the choices made by the school and in discussing the results considering the new limitations due to the COVID-19 pandemic and their consequences in term of sustainable food systems.

This paper reflects on the Italian case, which has been regarded as an innovative example of sustainable PFP [9,36-69]. The reflection is conducted starting from the results of an investigation carried out in an Italian school to shed light on: (i) whether parents wish to participate in the decision-making process of the school PFP and are likely to endorse options that are innovative and sustainable; (ii) the parents' perceptions of and influences on children's eating at school. The results are discussed in light of two important changes that have recently affected the Italian school PFP: the opening of school canteens to lunches brought from home in 2016 and the measures adopted since March 2020 to contain the COVID-19 pandemic. Both events go in the direction of transferring to the parents the responsibility of the school in the food sector. The article concludes that, based on the results of our study, this trend should be discouraged, while it would instead be beneficial to foster initiatives that promote the involvement of parents in school food choices.

\section{Background and Study Context}

\subsection{Italian School Public Food Procurement (PFP)}

In Italy, the school meal has traditionally been a tool to pursue social and environmental goals. As Oostindjer et al. [22] notes about other industrialized countries, Italian school food initiatives evolved with changing development objectives. After World War II, school canteens were pivotal in tackling hunger and malnutrition across the general population and in circulating the principles of healthy eating [70]. In the last few years, they have become places for the promotion of freshly produced, local and organic products. In 1999, Finance Law no. 488 [71] established a direct connection between public sector catering and the use of high-quality, local and organic food. Art. 59, comma 4, "Measures to facilitate the development of organic and quality agriculture" states that: "To guarantee the promotion of organic agricultural production of quality food products, public institutions that operate school and hospital canteens will include in the daily diet the use of organic, typical and traditional products as well as those from denominated areas. The awarding of catering contracts will be based on the quality of agricultural products offered." Thanks to the support of this "very innovative piece of legislation that establishes a direct and explicit link between organic and local food and public sector catering [9] (p. 71)", since the early 2000s the food quality standards and the sustainability of the service have greatly improved, building an increasingly careful and sensitive PFP. In 2017, the Italian Ministry of Agricultural, Food and Forestry Policies created a fund for organic school canteens, with a substantial financial endowment: 4 million euro in 2017, 10 million both in 2018 and 2019 and 5 million starting from 2020, cf. Decree Law no. 50 of 2017 [72].

Furthermore, by comprising the school meal within a much wider educational project, the Italian system makes it possible for public contractors to maintain control over each aspect of the service. Whereas several other countries have opted for cost-based contracting, which is centered on selecting low-cost contractors [2], in Italy catering contracts are awarded following the idea of 'best value', understood and assessed by considering not only the economic aspects (lowest price) but also the overall quality of the service and its compatibility with wider educational objectives [73].

The main purpose of the Italian school food education policy is defined by the Ministry of Education in the Guidelines for Food Education [74] (p. 19): "Food Education has as its ultimate goal the general improvement of the well-being of individuals, through the promotion of adequate eating habits, the elimination of unsatisfactory eating habits, the adoption of more hygienic food handling and the efficient use of food resources." Every food education activity must provide information about "safety; sensory characteristics; nutritional value; respect for the environment and resources in production, distribution and consumption; respect for the main ethical principles (social equity, animal welfare, etc.) 
in production and distribution; gratification in purchase and consumption [75] (pp. 11-12)". This goal is enriched by the need to complement the act of informing with an educational path that recognizes the complexity of eating behavior as a synthesis of physiological, psychological, social and cultural values. The school is understood, here, as a privileged place for the promotion of culture and relationships capable of "providing families and the community with the tools necessary to communicate and initiate a process of real change in eating habits [75] (p. 12)".

A broad set of education projects have been carried out in Italian schools to support this goal. To tackle health conditions ascribable to poor eating habits, e.g., children obesity, Italy has joined the European "Joint Action on Nutrition and Physical Activity", a program whose goal is to promote healthy eating at school [76] by means of its nutritional initiative "Gaining health" (Guadagnare salute) [77] and the school-based monitoring system called "Eye on health" (Okkio alla salute) [78].

The number of educational programs promoting healthy and sustainable food has undoubtedly grown in recent years [79]; nonetheless, enormous quantities of food waste are still produced by school canteens [80]; food neophobia, which is the unwillingness to eat types of food that are new or unusual, is widespread among children [81,82] and the share of overweight or obese children keeps increasing: $20.4 \%$ of Italian children are overweight and $9.4 \%$ obese, with higher values among children from families in the most disadvantaged socio-economic conditions [83].

\subsection{The Italian School Lunch}

In Italy, $75 \%$ of schools provide a school canteen service [84]. Hence, the majority of Italian children have lunch at school, i.e., at the kindergarten (children under 3 years of age), in nursery school (3-5 years), primary school (6-10 years) and middle school (11-13 years). School canteens serve both a mid-morning snack (mostly fruit) and lunch from Monday to Friday, from mid-September to mid-June, for a total of roughly 200 days a year. Younger children are usually given a one-hour lunchbreak, while primary and middle school children are allowed half an hour. A typical Italian meal includes a first course of complex carbohydrates (pasta or rice), a second course containing protein (meat, fish, eggs, cheese or legumes) along with a side serving (salad or cooked vegetables) and, lastly, fruit or dessert. Each course of the meal contributes to its overall nutritional quality.

The children cannot choose what to eat, because there is only one option for everybody, except those who follow a special diet for ethical, religious or health reasons. In addition, the portion sizes are pre-determined according to the pupils' age and skipping a course or having a second helping is not contemplated. Although the children can obviously leave what they do not like, the teachers-who sit and eat with them until primary school and are then replaced by educators, since the school lunch is a didactic moment-invite the pupils to eat their whole meal. Two menus are offered during the year depending on the season, i.e., a spring-summer menu and an autumn-winter menu. Differences in the recipes served also depend on the age of the students (kindergarten, nursery, primary and middle school). The menu changes every day of the week and the same weekly menu is served again after 3-4 weeks. This set of rules ensures great variety in the dishes prepared to meet the pupils' diverse tastes and promote high-quality eating.

\subsection{The Parents' Role}

The school canteen is a service on individual demand, provided by the municipalities. Families can decide whether to feed their children at school or bring them home for lunch and then take them back to school in the afternoon.

According to Pagliarino et al. [85] (p. 105), Italian families contribute to school PFP by paying for the cost of the meal (around $€ 5.00$ on average) in whole or in part, on the basis of family income. For what concerns the poorest families, the municipalities cover the complete cost of the service. 
Families can become involved in the school canteen committee, a representative body that enables them to monitor the service and have a say in PFP decisions (e.g., recipes, suppliers, etc.) [86].

In 2019 , in Italy, $81 \%$ of schools organize food education courses and $63 \%$ offer extracurricular activities regarding food, but parents take part in such activities in just $34 \%$ of the cases [84].

In 2016, 58 parents from the city of Turin appealed against the Municipality, responsible for the canteen service, and the Ministry of Education, to affirm the right of their children to eat at school food prepared at home. In its sentence no. 1049 of 2016, the Court of Appeal of Turin ruled that those parents had the right to have their children eat a meal in the school environment, but being able to choose between the menu available from the canteen and a meal brought from home. The same court then extended this right to all parents, paving the way for a home-prepared packed lunch for any family that prefers it [87].

Due to the COVID-19 pandemic, Italian schools were closed from March to June 2020. After the summer holidays, they reopened in mid-September 2020 and then closed again from October 2020 to April 2021, with a certain degree of heterogeneity among regions and school levels. The lessons continued online, but the canteen service was suspended throughout the closures, unlike what happened in other countries, where several strategies were developed to bring school meals to children's homes during the pandemic [88-90]. Conversely, Italian parents had to take care of their children's lunch without any help from the government.

\section{Materials and Methods}

The study was performed in the spring of 2015, in the municipality of Moncalieri (Moncalieri, in the province of Turin, Italy), in the "Nasi" state-run comprehensive school, which is attended by 1100 pupils distributed in 3 nursery, 4 primary and 1 middle school(s), with 10, 30 and 12 classes respectively, with an average of 20 students per class. The investigation was made possible thanks to the collaboration of the school management, teachers and canteen staff.

To shed light on whether the parents were keen on participating in the decisionmaking process of the school PFP and on supporting innovative and sustainable choices, in March 2015 the teachers were asked to administer a structured questionnaire to the whole population of families of the school. Some initial questions were intended to gather information on the respondents in terms of: (i) gender; (ii) number of family members; (iii) number of children and their gender; (iv) parents' job and perception of their own economic conditions. Then, the parents were asked if they would be interested in joining the school canteen committee, which is the representative body of families in charge of monitoring the quality of the service and proposing changes, for example, to recipes and suppliers. Next, the parents were made aware of the opportunity to introduce changes to the standard school menu in order to make it more sustainable, i.e., replacing frozen fish of heavily fished species with fresh fish from organic, local aquaculture farms, and they were asked if, in this case, they would accept to pay more for their children's school meal. Four potential price increase options ( $€ 0.03, € 0.06, € 0.09$ and $€ 0.12)$ were presented, corresponding to a realistic estimate of the price increase for each meal if the school canteen served fresh fish costing respectively $€ 1.00, € 2.00, € 3.00$ or $€ 4.00$ more than the frozen fish normally served [85] (p. 110). An option corresponding to no price increase (€0) was also included. An open-ended question allowed the parents to explain the reasons for their choice.

In April 2015, we performed an experiment to evaluate the parents' ability to predict what food their children would choose to eat at school, what impact the personal tastes of both parents and children have on food habits at school, the importance of being familiar with numerous kinds of food and the degree of responsible consumption by both parents and children. The experiment saw the participation of 138 parent/child pairs from two nursery school classes, an elementary school class and a group of students from all the 12 
middle school classes of the "Nasi" school. In middle school, only few families choose to benefit from the canteen service for their children and the kids have lunch at school only 1-2 days a week. For this reason, all the middle school kids eat together and not separated by classes, as is the case for nursey and primary school. For the nursery and elementary school, the classes were selected by the head of the school so that we could work with the most collaborative teachers. For the middle school group, we considered all the kids who attended the school canteen and their parents.

First, the school menu of a specific week was considered; it included the standard dishes normally served in the canteen, along with an innovative recipe, introduced because of its sustainability but unusual for the children and their parents, i.e., fillet of fresh trout, farmed in local and organic farms, instead of frozen fish fillets from heavily caught species, such as cod or flounder. Through a questionnaire, the parents were invited to provide their opinions in relation to each dish (around 20 recipes in total for each child, with some menu variations owing to differences depending on the pupils' age), on a 4-point Likert scale (not at all, not much, sufficiently, a lot) regarding:

- $\quad$ whether their children would appreciate the dish;

- whether their children would eat the dish, when the recipe was served the week after;

- whether they themselves appreciated the recipe;

- how frequently the dish was cooked at home (level of familiarity).

To conclude, the parents had to state whether they wanted to keep the recipe in question or remove it from their children's school menu.

The questionnaire was given by the teachers to the parents and then filled out at home, without input from the children, in the week before the menu was actually served in the school canteen (13-17 April 2015).

Immediately after lunch on each day of the week when the recipes were served, the pupils were invited to rate each of them using a similar questionnaire based on the same Likert scale (not at all, not much, sufficiently, a lot) concerning:

- whether they appreciated the recipe;

- whether they actually ate the dish.

To conclude, the children had to state whether they wanted to keep the recipe in question or remove it from the school menu. The questionnaire items were read out to the younger pupils, whereas middle-school children were considered more autonomous and were invited to complete the questionnaire by themselves.

In addition, the amount of food that each pupil ate was measured for each recipe and for each day of the week at the end of each meal. The leftovers on the plate were observed and consumption was estimated on the basis of the above Likert scale. The data provided by every child/parent pair were matched and kept as individual sets.

The data were processed by means of a descriptive statistical analysis, including pairwise correlation $(r)$, and by estimating two econometric models.

A logistic regression model (i.e., Model 1) makes it possible to study the direct relationship that links the binary variable, elimination_choice, referring to the parents' decision to maintain a recipe or remove it from their children's weekly school menu, to a set of potential explanatory variables, according to Equation (1):

- $\quad$ children's age and gender;

- parents' assumptions about their children's preferences (liking) and choices (consumption);

- children's school food attitude (squeamishness or adaptivity);

- parents' attitude toward the recipes in the school menu (familiarity and liking).

Log $\mathrm{p}($ elimination_choice $)=\alpha$ age $+\beta$ gender $+\delta$ liking $+\eta$ consumption $+\pi$ adaptivity + pfamiliarity + sparent_liking 
Squeamishness describes the children's propensity to refuse food if it is not to their liking. Conversely, adaptivity is the propensity of children to eat food even when they do not particularly appreciate it. In our database, this variable quantifies the children's actual propensity and not the parents' assumptions about their children's behavior. It is measured as the distance between the preferences expressed verbally by the children and the consumption actually measured in the canteen.

Next, a multiple linear regression model (i.e., Model 2) was estimated to identify the factors that have a stronger effect on the parents' ability to make predictions about their children's food consumption choices at school. In detail, we analyzed the relationship between the mistaken predictions made by the parents and a set of explanatory variables, which might be able to account for the children's and parents' personal traits and the parents' attitudes. Indeed, in addition to variables used in Model 1, the information on the age of parents has been added as an explanatory regressor. The model measures the continuous variable, consumption_prediction, in terms of distance, in absolute value, between the food consumption stated by the children and the related consumption predictions made by their parents, according to the following Equation (2).

consumption_prediction $=\alpha$ age $+\beta$ gender $+\delta$ parent_age $+\Omega$ parent_liking + pfamiliarity + ๆliking_prediction $+\varepsilon$

The level of consumption and the level of appreciation of a given recipe-based on a range of 4 equidistant values on the Likert scale, i.e., not at all, not much, sufficiently, a lot-are translated into numeric values between one and four. Also, the decision to keep a recipe or remove it from the school menu is expressed by a dummy variable, which is zero when the recipe is kept and one when it is discarded.

Table 1 presents some descriptive statistics on the dependent and independent variables used in our empirical analysis. Note that the number of observations is lower than 138 because of missing values in the questionnaires. Summery statistics refer to the whole sample considering all recipes.

Table 1. Descriptive statistics of dependent and independent variables.

\begin{tabular}{cccccc}
\hline Variable & Obs. & Mean & Std. Dev. & Min & Max \\
\hline elimination choice & 115 & 0.110179 & 0.167367 & 0 & 1 \\
age & 130 & 7.590361 & 2.771968 & 3 & 13 \\
gender & 130 & 0.549451 & 0.500305 & 0 & 1 \\
$\begin{array}{c}\text { parent's age } \\
\text { parents' prediction }\end{array}$ & 115 & 77 & 41.05195 & 6.149232 & 28 \\
$\begin{array}{c}\text { of children's liking } \\
\text { parents' prediction }\end{array}$ & 115 & 2.932272 & 0.42553 & 1.894737 & 4 \\
$\begin{array}{c}\text { of children's } \\
\text { consumption }\end{array}$ & 115 & 2.967161 & 0.52403 & 1.578947 & 4 \\
squeamishness & 115 & -0.03296 & 0.356672 & -0.84615 & 1.441176 \\
familiarity & 115 & 2.880965 & 0.470011 & 0 & 3.631579 \\
parents' liking & 115 & 3.328119 & 0.399382 & 2.157895 & 4 \\
\hline
\end{tabular}

The statistical software used for the calculations was Stata14.

Since the questionnaire submitted to all the families of the school was anonymous, it was not possible to know whether and how many of the 138 parents who participated in the experiment also answered the questionnaire. Therefore, the results of the two parts of the study (the questionnaire on the interest and willingness of parents towards school choices in PFP and the experiment on the relationships between food preferences and choices of parents and children) cannot be connected, even if they refer to the same population, but they contribute to the discussion in a complementary way. 


\section{Results}

Five-hundred parents whose children stay at school for lunch answered the questionnaire ( $45 \%$ of the number of children attending the school), aimed at assessing the families' interest in becoming members of the school canteen committee and willingness to pay for sustainable innovation in the school menu. It was the mother who filled out the questionnaire in $83 \%$ of the cases and the father in $17 \%$ of the cases. Of the families analyzed, $60 \%$ have two children, $17 \%$ one child, and the remaining families have between three and five children. Additionally, $72 \%$ of parents regard their economic condition as low or medium-low income.

Most parents (75\%) state that they are not interested in joining the school canteen committee, $23 \%$ of the parents would like to join, whereas $2 \%$ are already members.

Table 2 shows that most families are not willing to pay extra to make the school menu more sustainable (the scenario presented to them entailed introducing fresh fish of local varieties from organic farms to replace frozen fish of heavily fished species), since they believe that any additional costs for sourcing high quality and sustainable foods should already be covered by the current price of the school lunch.

Table 2. Parents' willingness to pay extra for including an innovative and sustainable recipe in the school menu.

\begin{tabular}{cc}
\hline Extra Price $(\boldsymbol{\epsilon})$ & Percentage of Families Willing to Pay the Extra Price \\
\hline 0.00 & 54 \\
0.03 & 6 \\
0.06 & 7 \\
0.09 & 9 \\
0.12 & 24 \\
\hline
\end{tabular}

The analysis focusing on the child/parent relations involved 138 pairs, whose distribution is shown in Table 3.

Table 3. Parent/child distribution in terms of school, age and gender.

\begin{tabular}{cccccc}
\hline \multicolumn{2}{c}{ Children's School } & \multicolumn{2}{c}{ Children's Gender } & \multicolumn{2}{c}{ Parents' Gender } \\
Typology & Number & Typology & Number & Typology & Number \\
\hline $\begin{array}{c}\text { Nursery school } \\
\text { (children aged } \\
\quad 3-5 \text { years) }\end{array}$ & 47 & girl & 80 & mother & 117 \\
$\begin{array}{c}\text { Primary school } \\
\text { (children aged } \\
\quad 8-9 \text { years) }\end{array}$ & 23 & boy & 58 & father & 14 \\
$\begin{array}{c}\text { Middle school } \\
\text { (children aged } \\
11-13 \text { years) }\end{array}$ & 68 & & & & \\
Total & 138 & & & no response & 7 \\
\hline
\end{tabular}

The analysis of the different variables describing the food choices of each parent/child pair yielded a large set of results, but the discussion in this article is limited to the data that might affect the PFP system, i.e., (i) the criterion based on which the parents decide to keep a recipe or remove it from the school menu; (ii) the parents' ability to predict which recipes their children will like at school, exploring in particular the different patterns of behavior in the case of traditional dishes vs. the innovative and sustainable dish.

Tables 4 and 5 present results for Model 1 in terms of marginal effects in order to improve the readability and the interpretation of the analysis. However, Appendix Tables A1 and A2 present the odds-ratio for Model 1. Table 4 indicates that the most important explanatory variable for the parents' decision to remove a recipe from the weekly school menu is their liking of the recipe. Indeed, results suggest that increasing the 
liking of parents about the recipe, the probability to remove it from the menu decreases by 59 percentage points. Logistic Model 1a. also reveals a very weak significant relationship between the food choices that the parents make for themselves and their children at home (familiarity) and the options that they recommend for their children at school. However, the parents' familiarity with the dishes on the school menu, measured according to their cooking frequency at home, is negatively correlated with the likelihood that the parents will remove them from the lunch menu. In addition, the model suggests that increasing the adaptability of children (i.e., squeamishness) significatively affects the probability of maintaining the recipe in the menu (i.e., -56 percentage points).

Table 4. Model 1a. Parents' recommended choice for the weekly school menu recipes (marginal effects). $n=115 ;$ pseudo R-squared $=0.3465$.

\begin{tabular}{|c|c|c|c|c|c|c|}
\hline Variable & $\mathrm{dy} / \mathrm{dx}$ & Std. Err. & $\mathbf{z}$ & $p>|z|$ & \multicolumn{2}{|c|}{ [95\% Conf. Interval] } \\
\hline Children's age & 0.1208173 & 0.03794 & 3.18 & 0.001 & 0.046463 & 0.195172 \\
\hline Children's gender & 0.2112746 & 0.15377 & 1.37 & 0.169 & -0.090119 & 0.512668 \\
\hline $\begin{array}{l}\text { Parents' prediction of } \\
\text { children's liking }\end{array}$ & 0.1349958 & 0.38646 & 0.35 & 0.727 & -0.622458 & 0.892449 \\
\hline $\begin{array}{l}\text { Parents' prediction of } \\
\text { children's } \\
\text { consumption }\end{array}$ & -0.2169935 & 0.33541 & -0.65 & 0.518 & -0.874392 & 0.440405 \\
\hline Squeamishness & -0.5603365 & 0.27729 & -2.02 & 0.043 & -1.10381 & -0.016858 \\
\hline Familiarity & -0.1040731 & 0.11424 & -0.91 & 0.362 & -0.327984 & 0.119838 \\
\hline Parents' liking & -0.5944093 & 0.26305 & -2.26 & 0.024 & -1.10998 & -0.078838 \\
\hline
\end{tabular}

Table 5. Model 1b. Parents' recommended choice for the innovative and sustainable recipe (marginal effects). $n=65 ;$ pseudo R-squared $=0.3936$.

\begin{tabular}{ccccccc}
\hline Variable & $\mathbf{d y} / \mathbf{d x}$ & Std. Err. & $\mathbf{z}$ & $p>|\mathbf{z}|$ & \multicolumn{2}{c}{ [95\% Conf. Interval] } \\
\hline $\begin{array}{c}\text { Children's age } \\
\text { Children's gender }\end{array}$ & 0.0616337 & 0.02624 & 2.35 & 0.019 & 0.010203 & 0.113065 \\
Parents' prediction of & -0.1217608 & 0.11742 & -1.04 & 0.3 & -0.351907 & 0.108386 \\
$\quad$ children's & -0.118511 & 0.06234 & -1.9 & 0.057 & -0.240689 & 0.003667 \\
consumption & & & & & & \\
$\quad$ Familiarity & -0.1396607 & 0.08514 & -1.64 & 0.101 & -0.306539 & 0.027218 \\
Parents' liking & -0.1983986 & 0.06645 & -2.99 & 0.003 & -0.328631 & -0.068166 \\
\hline
\end{tabular}

As the age of the children goes up, the frequency with which the parents remove recipes from the school menu increases sharply. Indeed, a positive and significant correlation exists between the variable measuring the age of the children and the frequency with which the parents decide to remove undesirable recipes from the weekly school menu (i.e., the increase of one year of age increases the probability to remove the recipe by 12 percentage points).

When considering an innovative and sustainable recipe (Model $1 \mathrm{~b}$ in Table 5), the parents' choice to keep it or eliminate it from their children's school menu is mostly determined by their assumptions about whether their children will enjoy the dish. In our experiment, the recipe featured fresh trout fillet from organic and local aquaculture, a product rarely used in collective catering services, where the most widely cooked fish belongs to varieties that can be readily transformed into already portioned and boned frozen slices or fillets, such as cod, plaice, etc. The parents are more likely to favor the new recipe if they think that their children will be eager to eat it at school (i.e., as parental satisfaction increases, the likelihood of food being removed from the canteen decreases by 12 percentage points). As expected, the familiarity variable has a small effect on this decision and the negative correlation is confirmed, while the variable accounting for the parents' appreciation of the recipe plays again a bigger role. As shown in Table 5, the parents tend 
to endorse the inclusion of the innovative recipe if they themselves appreciate it. Lastly, their tendency to be more selective as their children grow older remains unchanged.

The significant impact of consumption predictions on the parents' decision to retain or remove a recipe from the weekly school menu means that it is important to understand whether the parents are good at guessing their children's food choices at school.

As shown in Table 6, the parents' ability to predict what their children actually choose decreases in the case of an innovative recipe.

Table 6. Correlation between children's actual consumption and their parents' predictions about consumption.

\begin{tabular}{cc}
\hline Type of Recipe & Pairwise Correlation \\
\hline Weekly school menu recipes & $\mathrm{r}=0.52$ \\
Innovative and sustainable recipe & $\mathrm{r}=0.36$ \\
\hline
\end{tabular}

As Model 2a (Table 7) clearly indicates, mistakes in the parents' predictions about their children's food consumption are most ascribed to the parents' inaccuracy in predicting the level of appreciation. The less the parents are able to predict whether their children will like a dish, the more inaccurate they are in predicting consumption. If the parents know their children's food preferences well, then they are much better at guessing their children's choices in advance. Another element that can be gleaned from Model 2a is that the parents more accurately predict consumption at school in relation to types of food that are more regularly prepared at home. In fact, the mistakes made by the parents with regard to their children's lunch choices decrease as the parents' familiarity with the foods increases. Furthermore, prediction mistakes occur less frequently when the parents themselves enjoy the recipes in question. In brief, the parents are more often correct in predicting consumption for what concerns the types of food that they themselves like and frequently cook at home.

Table 7. Model 2a. Parents' predictions about their children's consumption of school menu recipes. $n=112$; R-squared $=0.5269 ;$ adj. R-squared $=0.4999$.

\begin{tabular}{ccccccc}
\hline Variable & Coefficient & Std. Err. & T & $p>|\mathbf{t}|$ & \multicolumn{2}{c}{ [95\% Conf. Interval] } \\
\hline Children's age & -0.0088716 & 0.0094813 & -0.94 & 0.352 & -0.0276712 & 0.009928 \\
Children's gender & 0.0005896 & 0.0545964 & 0.01 & 0.991 & -0.1076649 & 0.108844 \\
$\quad$ Parents' age & 0.0072212 & 0.0047207 & 1.53 & 0.129 & -0.0021391 & 0.016582 \\
Parents' liking & -0.12134 & 0.0693446 & -1.75 & 0.083 & -0.2588375 & 0.016157 \\
$\quad \begin{array}{c}\text { Familiarity } \\
\text { Parents' prediction of }\end{array}$ & -0.2052011 & 0.0625126 & -3.28 & 0.001 & -0.3291519 & -0.08125 \\
children's liking & 0.7083512 & 0.0780897 & 9.07 & 0 & 0.5535137 & 0.863189 \\
$\quad$ Constant & 1.040563 & 0.3097389 & 3.36 & 0.001 & 0.4264077 & 1.654718 \\
\hline
\end{tabular}

The addition of an innovative recipe seems to follow the same patterns detected in the case of traditional recipes (Table 8): the better the parents are at guessing in advance whether their children will appreciate a certain type of food, the more they are able to make accurate predictions about actual food consumption at school. Unsurprisingly, the familiarity variable is less significant in this situation, and the same is true for the variable referring to the parents' personal appreciation. 
Table 8. Model 2b. Parent's predictions about their children's consumption of an innovative and sustainable recipe. $n=52$; R-squared $=0.6373$; adj. R-squared $=0.5890$.

\begin{tabular}{ccccccc}
\hline Variable & Coefficient & Std. Err. & $\mathbf{T}$ & $p>|\mathbf{t}|$ & \multicolumn{1}{c}{ [95\% Conf. Interval] } \\
\hline Age & -0.0190192 & 0.0457199 & -0.42 & 0.679 & -0.1111039 & 0.073066 \\
Gender & 0.2699757 & 0.1566207 & 1.72 & 0.092 & -0.0454745 & 0.585426 \\
Parents' age & 0.0067821 & 0.0141406 & 0.48 & 0.634 & -0.0216986 & 0.035263 \\
Parents' liking & -0.0738171 & 0.0820699 & -0.9 & 0.373 & -0.2391144 & 0.09148 \\
Familiarity & 0.1578939 & 0.0954028 & 1.66 & 0.105 & -0.0342572 & 0.350045 \\
Prediction of liking & 0.6984663 & 0.0875601 & 7.98 & 0 & 0.5221111 & 0.874821 \\
Constant & 0.0514797 & 0.6100236 & 0.08 & 0.933 & -1.177171 & 1.28013 \\
\hline
\end{tabular}

Table 9 shows that the pupils choose innovative recipes more often ( 3.67 vs. 3.49$)$ and appreciate them more (3.03 vs. 2.83) than other recipes featured on the weekly school menu. Nonetheless, they are more likely to eliminate the innovative recipe than a more traditional one (0.41 vs. 0.39). As for the parents, they believe that their children will eat and enjoy traditional dishes more than the innovative recipe. When compared to the children's actual food behavior at school, the parents' predictions about appreciation and consumption are pessimistic, as confirmed by prediction values that are consistently lower than the actual values describing how children behave when they have lunch at school. Although the parents are much less willing to remove recipes from the school menu than their children, they too eliminate the innovative recipe more often than traditional recipes ( $0.28 \mathrm{vs}$. 0.15$)$.

Table 9. Comparison between children's actual food consumption and parents' predictions.

\begin{tabular}{|c|c|c|c|c|}
\hline \multirow[b]{2}{*}{ Variable } & \multicolumn{2}{|c|}{ Children's Behavior } & \multicolumn{2}{|c|}{ Parents' Prediction on Children's Behavior } \\
\hline & $n$ & Average & $n$ & Average \\
\hline Total recipes consumption & 135 & 3.49 & 119 & 2.87 \\
\hline Total recipes liking & 135 & 2.83 & 118 & 2.88 \\
\hline $\begin{array}{c}\text { Total recipes elimination } \\
\text { choice }\end{array}$ & 135 & 0.39 & 119 & 0.15 \\
\hline $\begin{array}{c}\text { Innovative recipe } \\
\text { consumption }\end{array}$ & 60 & 3.67 & 75 & 2.53 \\
\hline Innovative recipe liking & 80 & 3.03 & 72 & 2.57 \\
\hline $\begin{array}{l}\text { Innovative recipe } \\
\text { elimination choice }\end{array}$ & 80 & 0.41 & 75 & 0.28 \\
\hline
\end{tabular}

\section{Discussion}

The results of the study seem to suggest that the parents' greatest concern is that their children eat enough food during the school day. It seems this is the principle that helps them decide whether or not to keep a new recipe on the school menu, especially considering new, unfamiliar recipes. This conclusion is in line with those of other authors [91-93], who have highlighted that the priority for working-class mothers is to keep the children fed on a day to day basis. This attitude matches their behavior at home, where they more regularly cook the same recipes that they are inclined to keep on the school menu. The parents tend to recommend recipes that they cook at home and they are sure their children will like. These findings are consistent with Wardle et al. [94], according to which parents prefer to give their children the foods that they are most willing to accept.

When an innovative recipe is presented, the parents' main concern, i.e., consumption by their children at school, remains unchanged but, since they cannot rely on their familiarity with the food, they use their personal taste to guide their decisions. Also Skinner et al. [95] find that mothers tend not to introduce their children to foods that they themselves dislike. Parents seem to be unaware of the very tenuous correlation between adults' food preferences and those of their children, a phenomenon known as the "family paradox" [96-99]. 
In general, it appears that parents indulge their children's' food preferences, choosing recipes according to predictions about appreciation and consumption. As children grow older, parents become more selective, probably because they are aware that their children have become more selective too, although there is no consensus in the literature around this point. Several investigations have concluded that children's eating habits are relatively stable over time $[95,100,101]$, while others have found that children are more selective as they get older, reporting an age-related deterioration in the quality of their diets $[102,103]$.

Parents are not particularly good at making assumptions about their children's food choices at school. Their level of accuracy $(r=0.52$ for traditional recipes and $r=0.36$ for the new recipe) is no higher than the levels suggested in the literature for what concerns the ability to predict attitudes, interests and buying behavior of peers $(r=0.53)$ and spouses $(r=0.51)$ [104] or the accuracy of spouses in predicting each other's appreciation of new product concepts $(r=0.27)$ [105]. When compared with the values reported in research on how accurately parents predict their children's meal preferences and school lunch choices [106,107], the results of our study point to low reliability with regard to the parents' capacity to predict their children's actual consumption. The parents are more able to guess the choices of their children in relation to the foods that they cook most often at home and they know their children like. This evidence corroborates the conclusions of Mata et al. [106], pointing to the fact that parents do better when predicting what foods their children will enjoy than when guessing what they will not like.

As a rule, the parents do not seem eager to eliminate recipes from the school menu, which might seem like they trust the decisions made by the public administration and might also explain their lack of interest in joining the participatory decision-making body, i.e., the school canteen committee. This result is in line with Lareau [91], which reveals that working-class parents tend not to intervene in school-related matters because they value the expertise of educators and school officials.

Furthermore, the evidence illustrated here points to a low propensity of the parents toward the innovative and sustainable recipe, since they expect their children to eat and appreciate it less than other recipes and, as a consequence, tend to remove it more often. They do not show a great sense of responsibility toward more sustainable food choices and, at the same time, their predictions about the innovative dish are pessimistic. The children display the opposite behavior because, on average, they eat and enjoy the innovative recipe more than the more traditional ones, but they state that they want to eliminate the innovative recipe more often than the others.

The results of our study confirm that children's eating habits change between home and school, where they are influenced by the behavior of schoolmates and teachers [108-110]. Yet, as is widely held, children's food acceptance and choice are mostly driven by taste preferences and liking [111-118]. At the same time, several studies underline the powerful relationship between familiarity and preferences $[94,103,119]$. Parents can have a direct impact on their children's diets by increasing exposure to certain foods, preparing them more frequently at home and supporting the choices made in school canteens [120-124].

It is worth noting that, in Italy, the educational values attached to food eaten at school are expected to be conveyed not only to the children but also to their families [36] (p. 4). Hence, greater parental involvement in the education and decision-making processes would be extremely beneficial. For example, parents of pupils attending schools where interventions are carried out make overall healthier food choices when shopping than parents of students in control schools [122,125,126]. According to Morgan and Sonnino [36], parents should be empowered and knowledgeable actors who have the ability to make informed choices. Many scholars [65-68] argue that the role of all social actors, including parents, is essential for the success of food policies.

\section{Conclusions}

At present, in the Italian school system, parents can become involved, through the representative body of the canteen committee, in the definition of lunch menus, making 
proposals and asking for the elimination of recipes that they consider unwanted by the children. Our study suggests that, in this type of collaboration, parents are not very reliable because they are not good at predicting their children's choices and tend to eliminate recipes that they believe their children will not like, even though they are sustainable. For the same reason, the choice made by the Court of Appeal of Turin in 2016, which first gave children the right to eat a meal prepared at home during school time, also appears inappropriate. School meals significantly contribute to the daily food intake of students and are generally more nutritious than meals from other sources, including those brought from home [127], and more suitable for combating obesity [44,128]. This is especially true for students from underprivileged families, in which obesity and food insecurity are both higher since they are related to each other [83].

What might be beneficial, instead is for the parents of schoolchildren to take an active role in food education actions, so far almost completely neglected [84]. This would enable them to become precious allies in the innovation process pursued by the public administration aimed at achieving social and environmental goals.

In Italy, the COVID-19 pandemic heavily influenced the pursuit of these objectives. With the closure of schools, the canteen service was suspended without offering families any help, unlike what happened in other countries [86-88]; meanwhile, poverty was increasing [129]. The strategies adopted in many countries, but not in Italy, involved a great financial, organizational and logistic PFP effort, so that school meals could continue to reach the children and the staff employed in the sector could remain in service. These experiences will certainly need to be investigated further but, as of now, they represent a model of intervention in future crises.

The Italian school catering system made its voice heard only when Italian schools reopened, defining the measures that had to be adopted to counter the spread of the virus. From the examination of some guidelines available online [130-132], it emerges that the changes proposed revolve around the following aspects:

- to facilitate distancing during the meal, children can eat in the classroom, on other convenient school premises or in the refectory, but in shifts;

- to facilitate the distribution and consumption of meals, it is possible to use individual portions of food packed separately, single-dose packs of dressing, bread, water and fruit, disposable crockery, cutlery, tablecloths and napkins.

- $\quad$ to facilitate the service, it is possible to simplify the menus;

- to avoid unnecessary interpersonal contact, checks on the quality of the service by the parents (through the school canteen committee) are suspended.

These changes have a negative impact on the health and well-being of children and on the educational value of the school meal. One of the consequences is the production of more waste from disposable tableware and packaging of single portions. Also, the quality of the meals worsens due to simplification of the menus to contain costs and facilitate preparation, distribution and consumption (for example, soups are difficult to serve to classes on the upper floors of schools). The solution adopted in some canteens, of serving the first course, second course and side serving on the same plate, makes it easier for the children to eat only what they like best, with harmful consequences in terms of correct intake of nutrients, food waste, educational value, etc.

The need to maintain the correct temperature of the food until it is served and the fact that single portions tend to cool down quickly leads to a deterioration of the organoleptic characteristics of foods in heat-sealed single portions (for example, overcooked or very dry pasta).

The consumption of the meal in the classroom, on the other hand, involves positive changes at lunchtime, e.g., reduction in the noise typical of refectories, greater sharing between children and teachers, the opportunity for the children to be involved in the preparatory and post-meal activities (setting and clearing the table).

It is too early to draw any conclusions on the Italian measures and only in the future will it be possible to understand the consequences of these changes on the 2 million daily 
meals consumed in Italian schools [132]. Yet, the complex set of functions that the school canteen has been tasked to perform by Italy's public policies seems to clash with the absolute carelessness with which this system was suspended for months, after schools were closed due to the pandemic, while in the rest of the world solutions were found to continue bringing school meals to children and young people.

Author Contributions: Conceptualization, E.P. and E.S.; methodology, E.P., E.S. and G.F.; formal analysis, E.P., E.S. and G.F.; investigation, E.P. and E.S.; data curation, E.S. and G.F.; software, G.F.; resources, E.P.; validation E.P. and G.F.; visualization E.P.; writing—original draft preparation, E.S.; writing—review and editing, E.P. and G.F.; supervision, E.P.; funding acquisition, E.P.; project administration, E.P. All authors have read and agreed to the published version of the manuscript.

Funding: This research was funded by the Italian Ministry of Agricultural, Food and Forestry Policies (Ministero delle Politiche Agricole, Alimentari e Forestali-MIPAAF), grant number 67347 (24/12/2013), as part of the "Sano come un pesce biologico italiano-SANPEI II" research and development project aimed at studying and promoting organic aquaculture.

Institutional Review Board Statement: This study was conducted according to the guidelines of the Declaration of Helsinki and in compliance with the CNR Code of Conduct of 10/20/2017, whose observance is supervised by the Institute Director.

Informed Consent Statement: Informed consent was obtained from all subjects involved in the study.

Data Availability Statement: The data that support the findings of this study are not publicly available due to them containing information that could compromise research participant privacy but are available from the corresponding author on reasonable request.

Conflicts of Interest: The authors declare no conflict of interest. The funder of the research (MIPAAF) had no role in the design of the study, in the collection, analysis or interpretation of the data, in the writing of the manuscript, or in the decision to publish the results.

\section{Appendix A}

Table A1. Model 1a. Parents' recommended choice for the weekly school menu recipes (odds-ratio). $n=115$; pseudo R-squared $=0.3465$.

\begin{tabular}{ccccccc}
\hline Variable & Odds-Ratio & $\begin{array}{c}\text { Robust Std. } \\
\text { Err. }\end{array}$ & $\mathbf{z}$ & $p$ > | z | & [95\% Conf. Interval] \\
\hline $\begin{array}{c}\text { Children's age } \\
\text { Children's gender }\end{array}$ & 1.791411 & 0.3260657 & 3.2 & 0.001 & 1.2539 & 2.559338 \\
$\begin{array}{c}\text { Parents' prediction of } \\
\text { children's liking }\end{array}$ & 2.739554 & 2.037606 & 1.35 & 0.175 & 0.6376454 & 11.77011 \\
Parents' prediction of & 1.918267 & 3.62435 & 0.34 & 0.73 & 0.047278 & 77.83209 \\
$\quad$ children's & 0.3509535 & 0.5798367 & -0.63 & 0.526 & 0.0137694 & 8.94507 \\
consumption & & & & & & \\
Squeamishness & 0.0669437 & 0.0914475 & -1.98 & 0.048 & 0.0046019 & 0.9738252 \\
$\quad$ Familiarity & 0.605195 & 0.3288664 & -0.92 & 0.355 & 0.208616 & 1.755671 \\
Parents' liking & 0.0567942 & 0.0799538 & -2.04 & 0.042 & 0.0035975 & 0.8966223 \\
$\quad$ Constant & 4357.257 & $20,025.22$ & 1.82 & 0.068 & 0.533623 & $35,600,000$ \\
\hline
\end{tabular}

Table A2. Model 1b. Parents' recommended choice for the innovative and sustainable recipe (odds-ratio). $n=65 ;$ pseudo R-squared $=0.3936$.

\begin{tabular}{ccccccc}
\hline Variable & Odds-Ratio & $\begin{array}{c}\text { Robust Std. } \\
\text { Err. }\end{array}$ & $\mathbf{z}$ & $p>|\mathbf{z}|$ & \multicolumn{2}{c}{ [95\% Conf. Interval] } \\
\hline Children's age & 1.466693 & 0.258495 & 2.17 & 0.03 & 1.038295 & 2.071847 \\
Children's gender & 0.480823 & 0.371817 & -0.95 & 0.344 & 0.105623 & 2.188833 \\
\hline
\end{tabular}


Table A2. Cont.

\begin{tabular}{|c|c|c|c|c|c|c|}
\hline Variable & Odds-Ratio & $\begin{array}{c}\text { Robust Std. } \\
\text { Err. }\end{array}$ & $\mathbf{z}$ & $p>|z|$ & \multicolumn{2}{|c|}{ [95\% Conf. Interval] } \\
\hline \multicolumn{7}{|l|}{ Parents' prediction of } \\
\hline \multicolumn{7}{|l|}{ consumption } \\
\hline Familiarity & 0.419835 & 0.192798 & -1.89 & 0.059 & 0.1706816 & 1.03269 \\
\hline Parents' liking & 0.291443 & 0.109844 & -3.27 & 0.001 & 0.1392325 & 0.6100533 \\
\hline Constant & 14.73596 & 26.44333 & 1.5 & 0.134 & 0.4374386 & 496.409 \\
\hline
\end{tabular}

\section{References}

1. Robert, S.A.; Weaver-Hightower, M.B. School Food Politics: The Complex Ecology of Hunger and Feeding in Schools around the World; Peter Lang: New York, NY, USA, 2011.

2. De Schutter, O. The Power of Procurement: Public Purchasing in the Service of Realizing the Right to Food. Briefing Note 08 . 2014. Available online: http:/ / www.srfood.org/en/the-power-of-procurement-public-purchasing-in-the-service-of-realizingthe-right-to-food (accessed on 5 April 2021).

3. Gleason, P.M.; Suitor, C.W. Eating at School: How the National School Lunch Program Affects Children's Diets. Am. J. Agric. Econ. 2003, 85, 1047-1061. [CrossRef]

4. Pike, J.; Colquhoun, D. The relationship between policy and place: The role of school meals in addressing health inequalities. Health Sociol. Rev. 2009, 18, 50-60. [CrossRef]

5. Raulio, S.; Roos, E.; Prättälä, R. School and workplace meals promote healthy food habits. Public Health Nutr. 2010, 13, 987-992. [CrossRef]

6. Ashe, L.M.; Sonnino, R. At the crossroads: New paradigms of food security, public health nutrition and school food. Public Health Nutr. 2013, 16, 1020-1027. [CrossRef]

7. United Nations System Standing Committee on Nutrition (UNSCN). Schools as a System to Improve Nutrition: A New Statement for School-Based Food and Nutrition Interventions; Discussion Paper; UNSCN: Rome, Italy, 2017.

8. Morgan, K. Greening the Realm: Sustainable Food Chains and the Public Plate. Reg. Stud. 2008, 42, 1237-1250. [CrossRef]

9. Morgan, K.; Sonnino, R. The School Food Revolution: Public Food and the Challenge of Sustainable Development; Earthscan: London, UK, 2008.

10. Gelli, A.; Neeser, K.; Lesley, D. Home Grown School Feeding: Linking Small Holder Agriculture to School Food Provision; HGSF Working Paper Series 1; Partnership for Child Development: London, UK, 2010.

11. Sumberg, J.; Sabates-Wheeler, R. Linking agricultural development to school feeding in sub-Saharan Africa: Theoretical perspectives. Food Policy 2011, 36, 341-349. [CrossRef]

12. United States Department of Agriculture (USDA). Procuring Local Foods for Child Nutrition Programs; USDA: Washington, DC, USA, 2015.

13. Swensson, L.F.J. Institutional food procurement programmes and producer organizations catalysts for the transformation of small-scale producers' food supply systems. Redes 2019, 24, 30-44. [CrossRef]

14. Tartanac, F.; Swensson, L.F.J.; Polo Galante, A.; Hunter, D. Institutional food procurement for promoting sustainable diets. In Sustainable Diets Linking Nutrition and Food Systems; Burlingame, B., Dernini, S., Eds.; CAB International: Wallingford, UK, 2019; pp. 240-247.

15. Swensson, L.F.J.; Tartanac, F. Public food procurement for sustainable diets and food systems: The role of the regulatory framework. Glob. Food Sec. 2020, 25. [CrossRef]

16. Weaver-Hightower, M.B. Why education researchers should take school food seriously. Educ. Res. 2011, 40, 15-21. [CrossRef]

17. Benn, J.; Carlsson, M. Learning through school meals? Appetite 2014, 78, 23-31. [CrossRef]

18. McCrudden, C. Using public procurement to achieve social outcomes. Nat. Resour. Forum 2004, 28, 257-267. [CrossRef]

19. Fanzo, J.; Hunter, D.; Borelli, T.; Mattei, F. Diversifying Food and Diets: Using Agricultural Biodiversity to Improve Nutrition and Health; Routledge: London, UK, 2013.

20. De Schutter, O. Institutional food purchasing as a tool for food system reform. In Advancing Health and Well-Being in Food Systems: Strategic Opportunities for Funders; Global Alliance for the Future of Food, 2015; pp. 13-60.

21. Fitch, C.; Santo, R. Instituting Change: An Overview of Institutional Food Procurement and Recommendations for Improvement; The Johns Hopkins Center for a Livable Future: Baltimore, MD, USA, 2016.

22. Oostindjer, M.; Aschemann-Witzel, J.; Wang, Q.; Skuland, S.E.; Egelandsdal, B.; Amdam, G.V.; Schjøll, A.; Pachucki, M.C.; Rozin, P.; Stein, J.; et al. Are school meals a viable and sustainable tool to improve the healthiness and sustainability of children's diet and food consumption? A cross-national comparative perspective. Crit. Rev. Food Sci. Nutr. 2017, 57, 3942-3958. [CrossRef] [PubMed]

23. Tikkanen, I.; Urho, U. Free school meals, the plate model and food choices in Finland. Br. Food J. 2009, 111, 102-119. [CrossRef]

24. Jomaa, L.H.; McDonnell, E.; Probart, C. School feeding programs in developing countries: Impacts on children's health and educational outcomes. Nutr. Rev. 2011, 69, 83-98. [CrossRef] [PubMed] 
25. World Food Program (WFP). State of School Feeding Worldwide 2013; WFP: Rome, Italy, 2013.

26. World Food Program (WFP). Two Minutes to Learn about School Meals; WFP: Rome, Italy, 2015.

27. Kleine, D.; Brightwell, M.D.G. Repoliticising and scaling up ethical consumption: Lessons from public procurement for school meals in Brazil. Geoforum 2015, 67, 135-147. [CrossRef]

28. World Food Programme (WFP). State of School Feeding Worldwide 2020; WFP: Rome, Italy, 2020.

29. Hercberg, S.; Chat-Yung, S.; Chauliac, M. The French national nutrition and health program: 2001-2006-2010. Int. J. Public Health 2008, 53, 68-77. [CrossRef]

30. Caraher, M.N.; Crawley, H.; Lloyd, S. Nutrition Policy across the UK; Briefing Paper; The Caroline Walker Trust: Herts, UK, 2009.

31. Pietinen, P.; Männistö, S.; Valsta, L.M.; Srlio-Lähteenkorva, S. Nutrition policy in Finland. Public Health Nutr. 2010, 13, 901-906. [CrossRef]

32. Harper, C.; Wells, L. School Meal Provision in England and Other Western Countries: A Review; School Food Trust: London, UK, 2007.

33. Harper, C.; Wood, L.; Mitchell, C. The Provision of School Food in 18 Countries; School Food Trust: London, UK, 2008.

34. Lombardi, M.; Costantino, M. A Social Innovation Model for Reducing Food Waste: The Case Study of an Italian Non-Profit Organization. Adm. Sci. 2020, 10, 45. [CrossRef]

35. Rice, S.; Rud, A.G. Educational Dimensions of School Lunch Critical Perspectives; Palgrave Macmillan: London, UK, 2018. [CrossRef]

36. Morgan, K.; Sonnino, R. Empowering consumers: The creative procurement of school meals in Italy and the UK. Int. J. Consum. Stud. 2006, 31, 19-25. [CrossRef]

37. Winne, M. Education for change. J. Agric. Environ. Ethics 2005, 18, 305-310. [CrossRef]

38. Pyle, S.A.; Sharkey, J.; Yetter, G.; Felix, E.; Furlong, M.J.; Poston, W.S.C. Fighting an epidemic: The role of schools in reducing childhood obesity. Phycol. Sch. 2006, 43, 361-376. [CrossRef]

39. Greenhalgh, T.; Kristjansson, E.; Robinson, V. Realist review to understand the efficacy of school feeding programmes. BMJ 2007, 335, 858-861. [CrossRef] [PubMed]

40. Kristjansson, B.; Petticrew, M.; MacDonald, B.; Krasevec, J.; Janzen, L.; Greenhalgh, T.; Wells, G.A.; MacGowan, J.; Farmer, A.P.; Shea, B.; et al. School feeding for improving the physical and psychosocial health of disadvantaged students. Cochrane Database Syst. Rev. 2007, 1. [CrossRef] [PubMed]

41. Jaime, P.C.; Lock, K. Do school based food and nutrition policies improve diet and reduce obesity? Prev. Med. 2009, 48, 45-53. [CrossRef] [PubMed]

42. Capacci, S.; Mazzocchi, M.; Shankar, B.; Macias, J.B.; Verbeke, W.; Pérez-Cueto, F.J.A.; Kozioł-Kozakowska, A.; Piórecka, B.; Niedzwiedzka, B.; D'Addesa, D.; et al. Policies to promote healthy eating in Europe: A structured review of policies and their effectiveness. Nutr. Rev. 2012, 70, 188-200. [CrossRef]

43. Chriqui, J.F.; Pickel, M.; Story, M. Influence of school competitive food and beverage policies on obesity, consumption, and availability. JAMA Pediatr. 2014, 168, 279-286. [CrossRef] [PubMed]

44. Chang, C.; Jung, H. The role of formal schooling on weight in young children. Child. Youth Serv. Rev. 2017, 82, 1-12. [CrossRef]

45. Van Lancker, W. Putting the child-centred investment strategy to the test: Evidence for EU27. Eur. J. Soc. Secur. 2013, 15, 4-27. [CrossRef]

46. Oncini, F.; Guetto, R. Determinants of dietary compliance among Italian children: Disentangling the effect of social origins using Bourdieu's cultural capital theory. Sociol. Health Illn. 2017, 39, 47-62. [CrossRef]

47. Gaddis, J.; Coplen, A.K. Reorganizing school lunch for a more just and sustainable food system in the US. Fem. Econ. 2018, 24, 89-112. [CrossRef]

48. Filippini, M.; Masiero, G.; Medici, D. The demand for school meal services by Swiss households. Ann. Public Coop. Econ. 2014, 85, 475-495. [CrossRef]

49. Di Chiro, G. Living Environmentalisms: Coalition Politics, Social Reproduction, and Environmental Justice. Environ. Polit. 2008, 17, 276-298. [CrossRef]

50. Vania, A.; Pitzalis, G.; Mariani, P.; Marchione, S.A.; Monti, S.; Bonamico, M.; Falconeri, P.; Ferrante, E.; Imperato, C. Indagine nutrizionale su bambini romani di età prescolare che usufruiscono della refezione scolastica. La Rivista della Societá Italiana di Scienza dell'Alimentazione 1992, 21, 205-213.

51. Rossi, F.; Malvicini, G.; Pazzoni, A.; Maj, M.; Ciappellano, S. Rilevamento preferenze e consumi nella refezione scolastica. La Rivista della Societá Italiana di Scienza dell'Alimentazione 2006, 35, 25-34.

52. Verducci, E.; Radaelli, G.; Stival, G.; Salvioni, M.; Giovannini, M.; Scaglioni, S. Dietary macronutrient intake during the first 10 years of life in a cohort of Italian children. J. Pediat. Gastroenterol. Nutr. 2007, 45, 90-95. [CrossRef] [PubMed]

53. Vairano, P. Gli “obiettivi di salute" per la ristorazione collettiva: Evidenza e vincoli nei capitolati. In Ristorazione Collettiva: Non Solo Vigilanza; Unione Industriali: Naples, Italy, 2011.

54. Schwartz, M.B.; Brownell, K.D. Actions necessary to prevent childhood obesity: Creating the climate for change. J. Law Med. Ethics 2007, 35, 78-89. [CrossRef]

55. Suarez-Balcazar, Y.; Redmond, L.; Kouba, J.; Hellwig, M.; Davis, R.; Martinez, L.I.; Jones, L. Introducing system change in the schools: The case of school luncheons and vending machines. Am. J. Community Psychol. 2007, 39, 335-345. [CrossRef]

56. Stapleton, S.R. Parent activists versus the corporation: A fight for school food sovereignty. Agric. Hum. Values 2019, 36, 805-817. [CrossRef] 
57. Stapleton, S.R. Nevertheless, they persisted: How a group of 'noisy moms' overcame dismissal and helped to improve school food in a US small city school district. Gend. Place Cult. 2021, 28, 88-108. [CrossRef]

58. Persson Osowsky, C. The Swedish School Meal as a Public Meal: Collective Thinking, Actions and Meal Patterns. Ph.D. Thesis, Acta Universitatis Upsaliensis, Uppsala, Sweden, 2012.

59. Pike, J.; Leahy, D. School food and the pedagogies of parenting. Aust. J. Adult Learn. 2012, 52, 434-459.

60. Harman, V.; Cappellini, B. Mothers on display: Lunchboxes, social class and moral accountability. Sociology 2015, 49, 764-781. [CrossRef]

61. O'Flynn, G.H. Food, obesity discourses and the subjugation of environmental knowledge. Aust. J. Environ. Educ. 2015, 31, 99-109. [CrossRef]

62. Oncini, F. The holy gram: Strategy and tactics in the primary school canteen. J. Contemp. Ethnogr. 2018, 47, 640-670. [CrossRef]

63. Miller, T. Making Sense of Motherhood: A Narrative Approach; Cambridge University Press: Cambridge, UK, 2005.

64. Kalafa, A. Lunch Wars: How to Start a Food Revolution and Win the Battle for Our Children's Health; Penguin: New York, NY, USA, 2011.

65. Stein, M. Public sector food procurement in UK local authorities: Ethics and sustainability. In The Ethics of Consumption the Citizen, the Market and the Law; Röcklinsberg, H., Sandin, P., Eds.; Wageningen Academic Publishers: Wageningen, The Netherlands, 2013; pp. 395-398. [CrossRef]

66. Streiffer, R.; Piso, Z.; Sweeney, G.; Remley, D.; Forcone, T. An expanded understanding of the ethical importance of civic engagement in food sourcing decisions at the institutional level. Public Philos. J. 2018, 1. [CrossRef]

67. Hekimian-Williams, K. Developing a Sustainable Farm-to-School Lunch Program in Kauai, Hawaii; Patel College of Global Sustainability, University of South Florida: Tampa, FL, USA, 2016.

68. Filippini, R.; De Noni, I.; Corsi, S.; Spigarolo, R.; Bocchi, S. Sustainable school food procurement: What factors do affect the introduction and the increase of organic food? Food Policy 2018, 76, 109-119. [CrossRef]

69. Sonnino, R. Quality food, public procurement, and sustainable development: The school meal revolution in Rome. Environ. Plan. A 2009, 41, 425-440. [CrossRef]

70. Helstosky, C.F. Garlic and Oil: Food and Politics in Italy; Berg: Oxford, UK, 2006.

71. Gazzetta Ufficiale della Repubblica Italiana. Legge 23 Dicembre 1999, n. 488. Available online: https://www.gazzettaufficiale.it/ $\mathrm{eli} / \mathrm{id} / 2000 / 01 / 29 / 00$ A00641/sg (accessed on 7 May 2021).

72. Gazzetta Ufficiale della Repubblica Italiana. Testo Coordinato del Decreto-Legge 24 Aprile 2017, n. 50. Available online: https://www.gazzettaufficiale.it/eli/id/2017/06/23/17A04320/sg (accessed on 7 May 2021).

73. Ruffolo, U. Ristorazione Scolastica: Prospettive Giuridiche. In La Ristorazione Scolastica: Prospettive Future; Finocchiaro, R.B., Ed.; Institute for Research Studies and Information on the Agricultural Market (ISMEA), Ministero delle Politiche Agricole e Forestali: Rome, Italy, 2001; pp. 103-125.

74. Ministero dell'Istruzione, dell'Università e della Ricerca (MIUR). Linee Guida per l'Educazione Alimentare; MIUR: Rome, Italy, 2015.

75. Ministero dell'Istruzione, dell'Università e della Ricerca (MIUR). Linee Guida per l'Educazione Alimentare Nella Scuola Italiana; MIUR: Rome, Italy, 2011.

76. Joint Action on Nutrition and Physical Activity-JANPA. Available online: http:/ /janpa-toolbox.eu/ (accessed on 7 May 2021).

77. Guadagnare Salute. Available online: https://www.epicentro.iss.it/guadagnare-salute/ (accessed on 7 May 2021).

78. OKkio alla SALUTE. Available online: https://www.epicentro.iss.it/okkioallasalute/ (accessed on 7 May 2021).

79. Lambiase, M.; Bisagni, M. Mangiare a Scuola: Riflessioni e Proposte sui Percorsi di Educazione Alimentare Nella Scuola Italiana; Mattioli 1885: Fidenza, Italy, 2014.

80. Falasconi, L.; Vittuari, M.; Politano, A.; Segré, A. Food Waste in School Catering: An Italian Case Study. Sustainability 2015, 7, 14745-14760. [CrossRef]

81. Finistrella, V.; Manco, M.; Ferrara, A.; Rustico, C.; Presaghi, F.; Morino, G. Cross-sectional exploration of maternal reports of food neophobia and pickiness in preschooler-mother dyads. J. Am. Coll. Nutr. 2012, 31, 152-159. [CrossRef]

82. Laureati, M.; Bertoli, S.; Bergamaschi, V.; Leone, A.; Lewandowski, L.; Giussani, B.; Battezzati, A.; Pagliarini, E. Food neophobia and liking for fruits and vegetables are not related to Italian children's overweight. Food Qual. Prefer. 2015, 40, 125-131. [CrossRef]

83. Nardone, P.; Spinelli, A. Indagine Nazionale 2019: I Dati Nazionali 2020; Italian Ministry of Health: Rome, Italy, 2020.

84. Italian Ministry of Health. OKkio alla SALUTE-The Results 2019; Italian Ministry of Health: Rome, Italy, 2020.

85. Pagliarino, E.; Tron, S.; Leggio, K.; Agostini, P. La filiera del pesce fresco di allevamento biologico italiano dalla produzione alla ristorazione scolastica. In Sano Come un Pesce Ricerca e Innovazione Lungo la Filiera Acquacoltura-Ristorazione Scolastica; Pagliarino, E., Ed.; FrancoAngeli: Milan, Italy, 2013.

86. Galli, F.; Brunori, G.; Di Iacovo, F.; Innocenti, S. Co-producing sustainability: Involving parents and civil society in the governance of school meal services. A case study from Pisa, Italy. Sustainability 2014, 6, 1643-1666. [CrossRef]

87. Boggero, G. There is no such thing as a free lunch» Il pasto domestico a scuola come diritto costituzionalmente garantito? Oss. Cost. 2017, 3, 1-17.

88. Kinsey, E.W.; Hecht, A.A.; Dunn, C.G.; Levi, R.; Read, M.A.; Smith, C.; Niesen, P.; Seligman, H.K.; Hager, E.R. School Closures During COVID-19: Opportunities for Innovation in Meal Service. Am. J. Public Health 2020, 110, 1635-1643. [CrossRef] [PubMed]

89. Global Child Nutrition Foundation. COVID-19 \& School Meals around the World; Global Child Nutrition Foundation: Seattle, WA, USA, 2020. 
90. UK Department for Education. Guidance Providing School Meals during the Coronavirus (COVID-19) Outbreak; UK Department for Education: London, UK, 2021.

91. Lareau, A. Unequal Childhoods: Class, Race, and Family Life; University of California Press: Berkeley, CA, USA, 2003.

92. Wills, W.; Backett-Milburn, K.; Roberts, M.L.; Lawton, J. The framing of social class distinctions through family food and eating practices. Sociol. Rev. 2011, 59, 725-740. [CrossRef]

93. Wright, J.; Maher, J.; Tanner, C. Social class, anxieties and mothers' foodwork. Sociol. Health Illn. 2015, 37, 422-436. [CrossRef]

94. Wardle, J.; Sanderson, S.; Gibson, E.L.; Rapoport, L. Factor-analytic structure of food preferences in four-year-old children in the UK. Appetite 2001, 37, 217-223. [CrossRef]

95. Skinner, J.D.; Caruth, B.R.; Wendy, B.; Ziegler, P.J. Children's food preferences: A longitudinal analysis. J. Am. Diet. Assoc. 2002, 102, 1638-1647. [CrossRef]

96. Birch, L.L. The relationship between children's food preferences and those of their parents. J. Nutr. Educ. 1980, 12, 14-18. [CrossRef]

97. Rozin, P.; Fallon, A.; Mandell, R. Family resemblance in attitudes to food. Dev. Psychol. 1984, 20, 309-314. [CrossRef]

98. Pliner, P.; Pelchat, M.L. Similarities in food preferences between children and their siblings and parents. Appetite 1986, 7, 333-342. [CrossRef]

99. Rozin, P. Family resemblance in food and other domains: The family paradox and the role of parental congruence. Appetite 1991, 16, 93-102. [CrossRef]

100. Sweeting, H.; Anderson, A.; West, P. Socio-demographic correlates of dietary habits in mid to late adolescence. Eur. J. Clin. Nutr. 1994, 48, 736-748. [PubMed]

101. Lien, N.; Lytle, L.A.; Klepp, K.I. Stability in consumption of fruit, vegetables and sugary foods in a cohort from age 14 to age 21. Prev. Med. 2001, 33, 217-226. [CrossRef]

102. Lytle, L.A.; Seifert, S.; Greenstein, J.; McGovern, P. How do children's eating patterns and food choices change over time? Results from a cohort study. Am. J. Health Promot. 2000, 14, 222-228. [CrossRef]

103. Cooke, L.J.; Wardle, J. Age and gender differences in children's food preferences. Br. J. Nutr. 2005, 93, 741-746. [CrossRef] [PubMed]

104. Hoch, S.J. Perceived consensus and predictive accuracy: The pros and con of projections. J. Pers. Soc. Psychol. 1987, 53, 221-234. [CrossRef]

105. Davis, H.L.; Hoch, S.J.; Ragsdale, E.K.E. An anchoring and adjustment model of spousal predictions. J. Consum. Res. 1986, 13, 25-37. [CrossRef]

106. Mata, J.; Scheibehenne, B.; Todd, P.M. Predicting children's meal preferences: How much do parents know? Appetite 2008, 50, 367-375. [CrossRef]

107. Persson Osowski, C.; Fjellström, C.; Olsson, U.; Göranzon, H. Agreement between child and parent reports of 10- to 12-year-old children's meal pattern and intake of snack foods. J. Hum. Nutr. Diet. 2012, 25, 50-58. [CrossRef]

108. Birch, L.L. Effects of peer models' food choices and eating behaviors on preschoolers' food preferences. Child. Dev. 1980, 51, 489-496. [CrossRef]

109. Clendenen, V.I.; Herman, C.P.; Polivy, J. Social facilitation of eating among friends and strangers. Appetite 1994, 23 , 1-13. [CrossRef]

110. Herman, C.P.; Roth, D.A.; Polivy, J. Effects of the presence of others on food intake: A normative interpretation. Psychol. Bull. 2003, 129, 873-886. [CrossRef] [PubMed]

111. Birch, L.L. Preschool children's food preferences and consumption patterns. J. Nutr. Educ. 1979, 11, 189-192. [CrossRef]

112. Drewnowski, A. Taste preferences and food intake. Annu. Rev. Nutr. 1997, 17, 237-253. [CrossRef]

113. Resnicow, K.; Davis-Hearn, M.; Smith, M.; Baranowski, T.; Lin, L.S.; Baranowski, J.; Doyle, C.; Wang, D.T. Social-cognitive predictors of fruit and vegetable intake in children. Health Psychol. 1997, 16, 272-276. [CrossRef]

114. Gibson, E.L.; Wardle, J.; Watts, C.J. Fruit and vegetable consumption, nutrition knowledge and beliefs in mothers and children. Appetite 1998, 31, 205-228. [CrossRef] [PubMed]

115. Baxter, S.D.; Thompson, W.O.; Harry, C.; Davis, M.S. Fourth grade children's observed consumption of, and preferences for, school lunch foods. Nutr. Res. 2000, 20, 439-443. [CrossRef]

116. Baxter, S.D.; Thompson, W.O. Fourth-grade children's consumption of fruit and vegetable items available as part of school lunches is closely related to preferences. J. Nutr. Educ. Behav. 2002, 34, 166-171. [CrossRef]

117. Perez-Rodrigo, C.; Ribas, L.; Serra-Majem, L.; Aranceta, J. Food preferences of Spanish children and young people: The enKid study. Eur. J. Clin. Nutr. 2003, 57, 45-48. [CrossRef] [PubMed]

118. Caporale, G.; Policastro, S.; Tuorila, H.; Monteleone, E. Hedonic rating and consumption of school lunch among preschool children. Food Qual. Prefer. 2009, 20, 482-489. [CrossRef]

119. Birch, L.L.; Marlin, D.W. I don't like it; I never tried it: Effects of exposure on two-year-old children's food preferences. Appetite 1982, 3, 353-360. [CrossRef]

120. Contento, I.R.; Manning, A.D.; Shannon, B. Research perspective on school-based nutrition education. J. Nutr. Educ. 1992, 24, 247-260. [CrossRef]

121. Contento, I.; Balch, G.I.; Bronner, Y.L. The effectiveness of nutrition education and implications for nutrition education policy, programs and research: A review of research. J. Nutr. Educ. 1995, 27, 279-380. 
122. Lytle, L.; Achterberg, C. Changing the diet of American's children: What works and why? J. Nutr. Educ. 1995, 27, 250-260. [CrossRef]

123. Burgess, A.L.; Bunker, V.W. An investigation of school meals eaten by primary schoolchildren. Br. Food J. 2002, 104, 705-712. [CrossRef]

124. Salvy, S.J.; Vartanian, L.R.; Coelho, J.S.; Jarrin, D.; Pliner, P.P. The role of familiarity on modeling of eating and food consumption in children. Appetite 2008, 50, 514-518. [CrossRef] [PubMed]

125. Reynolds, K.D.; Franklin, F.A.; Binkley, D.; Raczynski, J.M.; Harrington, K.F.; Kirk, K.A.; Person, S. Increasing the fruit and vegetable consumption of fourth-graders: Results from the high 5 project. Prev. Med. 2000, 30, 309-319. [CrossRef]

126. Lytle, L.A.; Kubik, M.Y.; Perry, C.; Story, M.; Birnbaum, A.S.; Murray, D.M. Influencing healthful food choices in school and home environments: Results from the TEENS study. Prev. Med. 2006, 43, 8-13. [CrossRef]

127. Au, L.E.; Gurzo, K.; Gosliner, W.; Webb, K.L.; Crawford, P.B.; Ritchie, L.D. Eating school meals daily is associated with healthier dietary intakes: The Healthy Communities Study. J. Acad. Nutr. Diet. 2018, 118, 1474-1481. [CrossRef]

128. Decataldo, A.; Fiore, B. Is eating in the school canteen better to fight overweight? A sociological observational study on nutrition in Italian children. Child. Youth Serv. Rev. 2018, 94, 246-256. [CrossRef]

129. Censis. La Società Italiana al 2020; 54 Rapporto Censis; Censis: Rome, Italy, 2020.

130. Città Metropolitana di Milano. Ristorazione Scolastica in Relazione al Rischio COVID-19: Riflessioni in Occasione della Riapertura dell'Anno Scolastico 2020-2021; Città Metropolitana di Milano: Milan, Italy, 2020.

131. Regione Emilia Romagna. Indicazioni Tecniche per la Ristorazione Scolastica in Relazione al Rischio COVID-19; Regione EmiliaRomagna: Bologna, Italy, 2020.

132. Società Italiana di Igiene Medicina Preventiva e Sanità Pubblica (SItI). Linee di Indirizzo SItI—COVID-19 e Ristorazione Scolastica; SItI: Rome, Italy, 2020. 